\title{
ОСОБЛИВОСТІ МЕДИЧНОЇ ЕТИКИ ТА ДЕОНТОЛОГІЇ
}

\author{
Я. М. Попович \\ ДВНЗ «Тернопільський державний медичний університет \\ імені І. Я. Горбачевського МОЗ Украӥни"
}

У статті наведено особливості медичної етики і деонтології, а також принципи, які необхідно знати і дотримуватися медичним сестрам.

\section{FEATURES OF MEDICAL ETHICS AND DETONTOLOGY}

\section{Y. M. Popovych}

\section{Horbachevsky Ternopil State Medical University}

The article presents the features of medical ethics and deontology, as well as the principles that must be known and followed by nurses.

Вступ. Історія медицини і практичний досвід охорони здоров'я з усією очевидністю показують, що «медична допомога не може бути повноцінною, якщо сам високопрофесійний медичний працівник не володіє необхідними етичними якостями» [4]. Етика (від грец. ethos - звичай, вдача) - одна з найдавніших теоретичних дисциплін, об'єктом вивчення якої $\epsilon$ мораль, моральність.

Медична етика - це сукупність норм поведінки і моралі медичних працівників.

Під медичною етикою розуміють поєднання моральних норм, яких мають дотримуватися медичні працівники в ході виконання своїх професійних обов'язків. При цьому медична етика тісно пов'язана з медичною деонтологією - вченням про проблеми моралі та моральності, що є розділом етики. Деонтологія головним чином визначає норми взаємовідносин медичного працівника і пацієнта.

Основна частина. Відомо, що, «крім загальних моральних норм, що регулюють життя суспільства, існують норми класичної медичної етики, які мають свою специфіку, пов'язану з природою самої професії» [5].

Поряд із терміном «медична етика» часто застосовують термін «деонтологія» (від грец. deon - належне, борг i logos - вчення, слово) - вчення про належну поведінку медичних працівників. Вперше це поняття було введено на початку XIX ст. англійським юристом і філософом І. Бентамом [8].

(с) Я. М. Попович, 2018
Деонтологія $є$ складовою частиною медичної етики і має більш конкретний характер стосовно окремих медичних спеціальностей.

Саме тому поняття «медична етика» і «деонтологія» органічно пов'язані, оскільки мають справу $з$ моральними та етичними нормами і основаними на них принципами і правилами поведінки медичних працівників, які виконують свій громадянський і професійний обов'язок. У реальному житті дотримання деонтологічних правил доповнюється певним морально-етичним змістом.

Основні аспекти медичної етики можна узагальнити таким чином:

- медичний працівник і суспільство;

- моральні якості й зовнішній вигляд медичного працівника;

- медичний працівник і пацієнт;

- медичний працівник і родичі пацієнта;

- медична таємниця;

- взаємини представників медичних професій;

- удосконалення знань;

- етика експерименту [1].

Морально-етичні аспекти відіграли основну роль в діяльності сестри милосердя в усі часи. Власне, сама професія виросла з бажання жінки допомогти хворому або пораненому. Жінки, черниці або мирянки, присвячували все своє життя цьому високому служінню. Святе Письмо оповідає про те, що ще в початковий період християнства з'явилися люди, спонукувані 
любов'ю і співчуттям, які добровільно присвятили себе догляду за хворими та пораненими, - брати і, що особливо знаменно, сестри милосердя, імена яких зустрічаються в посланнях апостолів. Серед учнів і послідовників Ісуса Христа були групи жінок, які називались Громадою святих жон, які супроводжували Спасителя і служили від його імені.

I тому коли в середині XIX ст. практично одночасно в Англії і в Росії з'явилися професійні сестри милосердя (тобто жінки, які мають не тільки бажання служити ближньому, а й володіли певними медичними знаннями і навичками), в основу їх професії лягли ті ж етичні принципи. «Наріжним каменем філософії сестринського руху служить уявлення про рівне право на милосердя до будь-якої людини, незалежно від її національності, соціального статусу, віросповідання, віку, характеру хвороби і т. д.» [6].

Засновниця професії сестри милосердя Ф. Найтінгейл тоді ж дала визначення сестринської справи як «одного з найдавніших мистецтв і однієї з наймолодших наук, яка концентрується на турботі про пацієнтів» [2]. Вперше в історії вона висловила тверде переконання в тому, що «... по суті своїй сестринська справа як професія відрізняється від лікарської діяльності і вимагає спеціальних, відмінних від лікарських знань» [2]. Вищою оцінкою професійного служіння медичної сестри є медаль імені Флоренс Найтінгейл, заснована Міжнародним комітетом Товариств Червоного Хреста і Червоного Півмісяця.

Медична етика включає такі принципи: конфіденційність, етику, інформовану згоду, правову і судову медицину. Взаємовідносини медпрацівників із пацієнтами та їхніми родичами і взаємостосунки медичних працівників між собою $є$ також частиною етики медичних працівників. Усі медичні працівники зобов'язані дотримуватися суворого кодексу етики.

Професійна діяльність медичної сестри полягає в догляді за пацієнтами, наданні їм психологічної підтримки, полегшенні фізичних страждань [7]. Медичній сестрі необхідно знати і дотримуватися принципів медичної етики, які включають повідомлення пацієнтів про їхні права, стан здоров'я, гуманне ставлення і повагу до людської гідності хворого. Медсестри не можуть розкривати інформацію про пацієнта без його згоди. Оскільки медичні сестри взаємодіють з сім'єю пацієнта, вони повинні дотримуватися етичних принципів, враховуючи розкривати або не розкривати дані про стан здоров'я хворого. Кожна медична сестра клініки має зобов'язання щодо захисту здоров'я, прав і безпеки пацієнтів. Фізична недоторканність приватного життя пацієнта - частина принципів медичної етики.

Медична сестра, фельдшер, акушерка (далі медична сестра) повинні поважати невід'ємні права кожної людини на досягнення найвищого рівня фізичного та психічного здоров'я і на отримання адекватної медичної допомоги.

Медична сестра зобов'язана надавати пацієнту якісну медичну допомогу, що відповідає принципам гуманності, професійним стандартам, і нести моральну відповідальність за свою діяльність перед пацієнтом, колегами і суспільством [9].

Основна умова сестринської діяльності - професійна компетентність. Медична сестра повинна завжди дотримуватися і підтримувати професійні стандарти діяльності. Безперервне вдосконалення спеціальних знань і умінь, підвищення свого культурного рівня найперший професійний обов'язок медичної сестри. Вона повинна бути компетентною також щодо моральних і юридичних прав пацієнта.

Медична сестра повинна понад усе ставити співчуття і повагу до життя пацієнта, зобов'язана поважати право пацієнта на полегшення страждань в тій мірі, в якій це дозволяє існуючий рівень медичних знань. Вона не має права брати участь в тортурах, стратах та інших формах жорстокого і нелюдського поводження з людьми, сприяти самогубству хворого.

Необхідною умовою $є$ повага до людської гідності пацієнта. Медична сестра не має права порушувати давню етичну заповідь медицини «Перш за все - не нашкодь!» [5], а також байдуже ставитися до дій третіх осіб, які прагнуть нанести пацієнтові шкоду. Дії медичної сестри із догляду за пацієнтом, будь-які інші медичні втручання, пов'язані з больовими відчуттями та іншими тимчасовими негативними явищами, припустимі лише в його інтересах.

Моральний обов'язок медичної сестри - інформувати пацієнта про його права. Вона зобов'язана поважати право пацієнта на отримання інформації про стан його здоров'я, про можливий ризик і переваги пропонованих методів лікування, про діагноз і прогноз. 3 огляду на те, що функція інформування пацієнта і його близьких, переважно, належить лікарю, медична сестра має моральне право передавати професійні відомості лише за погодженням із лікуючим лікарем як члена бригади, яка обслуговує даного пацієнта. У виняткових випадках, медична сестра має право приховати від пацієнта професійну інформацію, 
якщо вона переконана, що остання заподіє йому серйозної шкоди.

Медична сестра повинна поважати право пацієнта або його законного представника (коли вона має справу з дитиною або недієздатним психічно хворим) погоджуватися на будь-яке медичне втручання або відмовлятися від нього. Вона повинна бути впевнена, що згода або відмова дані пацієнтом добровільно і усвідомлено. її моральний і професійний обов'язок - роз'яснювати пацієнтові в міру своєї кваліфікації наслідки відмови від медичної процедури. Відмова пацієнта не повинна впливати на його стан і негативно відображатися на ставленні до нього медичної сестри та інших медичних працівників.

Медсестра має право надавати допомогу без згоди пацієнта (або без згоди законного представника некомпетентного пацієнта - дитини до 15 років або недієздатного душевнохворого) тільки в строгій відповідності до законодавства. При наданні медичної допомоги некомпетентним пацієнтам медична сестра повинна, наскільки дозволяє стан таких пацієнтів, залучати їх до процесу прийняття рішення.

Медична сестра повинна з повагою ставитися до права вмираючого пацієнта на гуманне поводження і гідну смерть. При цьому вона зобов'язана володіти необхідними знаннями та вміннями в сфері паліативної медичної допомоги, що дає вмираючому можливість закінчити життя з максимально можливим фізичним, емоційним і духовним комфортом. Найперші моральні та професійні обов'язки медичної сестри: запобігання і полегшення страждань, як правило, пов'язаних із процесом вмирання; надання вмираючому і його сім'ї психологічної підтримки. Евтаназія, тобто навмисні дії з метою припинення життя вмираючого пацієнта, навіть на його прохання, неетична і неприпустима, хоча ставлення до цієї проблеми в суспільстві неоднозначно [3].

Медична сестра повинна ставитися шанобливо до померлого пацієнта. При обробці тіла слід враховувати релігійні та культурні традиції.

Вона повинна прагнути брати участь у дослідницькій діяльності, у примноженні знань у своїй професії.

Завжди гостро стояло питання ставлення до тієї чи іншої форми подяки з боку пацієнта. Медична сестра повинна відмовлятися від подарунків і приємних пропозицій з боку пацієнта, якщо в основі лежить його бажання домогтися привілейованого становища порівняно з іншими пацієнтами. Але при цьому має право прийняти подяку від пацієнта, якщо вона ви- ражається в формі, яка не принижує людської гідності обох, чи не суперечить принципам справедливості та порядності й не порушує правових норм. Інтимні стосунки з пацієнтом засуджуються медичною етикою.

Медична сестра зобов'язана точно і кваліфіковано проводити призначені лікарем медичні маніпуляції відповідно до переліку медичних послуг. Високий професіоналізм медичної сестри - найважливіший фактор товариських, колегіальних взаємовідносин медичної сестри і лікаря. Фамільярність, неслужбовий характер взаємовідносин лікаря і медичної сестри при виконанні ними професійних обов'язків засуджуються медичною етикою. Якщо медична сестра сумнівається в доцільності лікувальних рекомендацій лікаря, вона повинна тактовно обговорити цю ситуацію спочатку з самим лікарем, а при збереженні сумнівів і після цього - з вищим керівництвом [3].

Стикнувшись з фактами нелегальної, неетичної або некомпетентної практики, медична сестра повинна ставати на захист інтересів пацієнта і суспільства.

Висновки. Від медсестри потрібен не тільки високий професіоналізм, а й вміння дотримуватися норм етико-деонтологічного спілкування з колегами і пацієнтами. Медична деонтологія - це вчення про обов'язок медичних працівників перед пацієнтами. Все - для блага пацієнта. Медична сестра більшу частину професійної діяльності перебуває з пацієнтом, при цьому вона повинна виконувати керівну, виховну і освітню роботу. Для пацієнта, який прийнятий до лікувального закладу, важливо не тільки лікування, але і те, як його зустріли медичні працівники. В умовах лікувального закладу перший контакт пацієнта з медичним персоналом і, зокрема з медичною сестрою, має особливо важливе значення; саме він надалі визначає взаємини - почуття довіри чи недовіри, приязні чи неприязні, наявність або відсутність партнерських відносин. Тому етика і деонтологія в діяльності медичної сестри мають особливе значення. Особистість медичної сестри, методи їі роботи, уміння поводитися з пацієнтами, володіння технікою психологічної роботи з ними - все це само по собі може слугувати ліками, надавати зцілювальний вплив. При побудові взаємовідносин «медсестра-пацієнт» велике значення має індивідуальний стиль роботи та індивідуальні особливості медичної сестри. Найважливішими якостями медичної сестри вважають: шанобливе ставлення до пацієнтів; прагнення допомагати; увага; терпимість; доброта; ввічливість; душевність. Все в медичній сестрі має викликати прихильність до себе 
пацієнта, і тільки тоді виникає довірчий діалог, під час якого медсестра дізнається необхідні їй відомості про пацієнта, особливості його особистості, його думку про захворювання, госпіталізацію, плани на майбутнє.

\section{СПИСОК ЛІТЕРАТУРИ}

1. Лещинский А. А. Медицинская этика и деонтология / А. А. Лещинский. - Ижевск, 2005. - 250 с.

2. Сурожский А. О медицинской этике / А. Сурожский // Независимый психиатрический журнал. - 1995. Вып. 1. - С. 46-54.

3. Островская И. В. Медицинская этика. Сборник документов / И. В. Островская. - М. : АНМИ, 2001. - 40 с.

4. Иванюшкин А. Я. История и этика сестринского дела : учебное пособие / А. Я. Иванюшкин, А. К. Хетагурова. - М. : ГОУ ВУНМЦ МЗ РФ, 2003. - 132 с.

5. Иванюшкин А. Я. Этика сестринского дела / А. Я. Иванюшкин. - М. : ГРАНТ, 2003. - 168 с.
Важливу роль відіграє зовнішній вигляд, вираз обличчя, мова медсестри, адже вона єхарактеристикою фахівця і повинна відповідати нормам.

6. Сестринское дело / под ред. А. Ф. Краснова. - Самара : ГП «Перспектива», 1998. - Т. 1. - 350 с.

7. Алексеева Е. Б. Воспитание нравственно-этической культуры медицинских сестер лечебного учреждения [Электронный ресурс] / Е. Б. Алексеева // Международный журнал экспериментального образования. - 2014. - № 10. С. 22-25. - Режим доступа : https://expeducation.ru/ru/ article/view?id=6007.

8. Деонтология в медицине : в 2 т. / под ред. Б. В. Петровского. - М. : Медицина, 1988. - 506 с.

9. Сединкина Р. Г. Сестринское дело в терапии. Раздел «Кардиология» / Р. Г. Сединкина; под ред. Е. Ю. Куранова. - М. : ГЕОТАР-Медиа, 2013. - 272 с. 